\title{
HET DEPARTEMENT VAN LANDBOUW-ECONOMISCHE ZAKEN IN SURINAME IN 1945
}

DOOR

\section{IR J. J. vaN Wouw}

Wij schrijven dit overzicht, naar aanleiding van het Jaarverslag van het Departement van Landbouw-Economische Zaken over 1945, dat ons werd toegezonden.

Het bereikte ons eerst dit jaar, zodat de bespreking wei wat heel laat uitvalt en veel wat in het verslag staat vermeld, inmiddels weer zal zijn veranderd of door de feiten achterhaald.

Toch mag dit naar onze mening geen reden zijn, om over het verslag te zwijgen. Er staan teveel belangrijke en wetenswaardige feiten in, waarop wij de aandacht zouden willen vestigen. Het zou echter wel aanbeveling verdienen dat het Departement, wil het de belangstelling gaande houden, voortaan dergelijke verslagen spoediger doet rondzenden. Ik weet echter wel, dit zij al dadelijk ter vergoelijking gezegd, met welke moeilijkheden men in Suriname te kampen heeft, vóórdat een dergelijk verslag in elkaar zit.

Vele bijdragen, feiten en gegevens moeten uit de districten komen en verzameld worden door personeel, dat voortdurend op reis is en zelf weinig tijd over heeft, om daar extra voor te gaan zitten. Dan moeten zij nog naar Paramaribo worden opgezonden, bekeken en geschrift, gepolijst en tot een geheel worden samengevoegd en dat is waarlijk geen geringe zaak. Vooral niet, wanneer een en ander, zoals gebruikelijk, niet klopt en teruggezonden moet worden met verzoek om revisie.

Het is allemaal zo eenvoudig niet als hier in Holland. De personeelsbezetting die in het verslag op blz. 4 voor 1945 wordt gegeven, laat al wel zien, hoe moeilijk het is om datgene te doen, wat ervan verwacht wordt en, zoals met meer Departementen in Paramaribo het geval is, ook voor het Departement van Landbouw-Economische Zaken geldt het woord, al klinkt het dan ook 
een beetje te geweldig: „Nooit werd door weinigen zoveel verricht".

De naam ,Departement” voor deze instelling is overigens dan ook wel zeer wijds en vooral als men bedenkt, wat de argeloze lezer, die de verhoudingen in Suriname niet kent, niet daderijk opvalt, dat (1945) onder het Departement van Landbouw-Economische Zaken het Landbouw-Proefstation niet wordt begrepen (dit is weer een ander „Departement”) dan zal men begrijpen, dat een oordeel over de activiteit van Landbouw-Economische Zaken, althans een billijk oordeel, niet zo gemakkelijk is.

Als men het verslag leest, kan men niet aan de indruk ontkomen, ook al is dat zoals ik boven al aankondigde, begrijpelijk, dat er toch nog heel veel in Suriname ongedaan blijft op Landbouwgebied. Oók met inachtneming van de overweging (maar al te vaak wordt dit op beoordeling van tropische zaken over het hoofd gezien), dat Suriname Nederland niet is.

Men heeft hier immers dikwijls geen volledig besef van de totaal andere normen die in een land als Suriname moeten worden aangelegd.

Maar toch zoals ik zei, men kan niet aan de indruk ontkomen, dat er niet genoeg gedaan wordt. Ik zal wel de laatste zijn om dat aan de Directeur en zijn personeel, dat ik persoonlijk ken, en waarmee banden van vriendschap en aangename samenwerking mij steeds hebben verbonden, te verwijten. Ik weet het goed, hoe ontstellend klein de credietjes zijn, waarmede het Departement moet woekeren, hoe groot het tekort aan personeel en hoe klein, niettegenstaande de grote belangstelling van allen die met de Landbouw ook maar iets te maken hebben, in vele gevallen de medewerking van sommige zijden uitvalt.

Een frappant voorbeeld daarvan is wel de geremde activiteit van de uiterst bekwame dierenarts Dr. J. Frickers, die jaren lang met zoveel toewijding in het belang van de veestapel van Suriname werkzaam was, en van wien Suriname zoveel meer had kunnen profiteren.

Een bijdrage van zijn hand treft men in het jaarverslag aan, in de vorm van een overzicht der door zijn dienst ter hand genomen objecten, van blz. 18 tot blz. 91. Met de verhandeling van Mevr. C. E. Droogleever Fortuyn over waarnemingen m.b.t. het legeren van variëteiten van rijst, neemt Dr. Frickers' bijdrage het leeuwendeel van het hele verslag in.

Behalve het uiterst interessante rapport over het voorkomen van varkenspest, enkele eveneens interessante opgaven van ge- 
bruik van vers- en verduurzaamd vlees in Suriname en een overzicht van de Landsboerderij Beekhuizen, is voor mij toch wel zijn opstel over het Zandsavannen veeteelt-vraagstuk in Suriname het belangrijkst.

Dr. Frickers geeft daarin een uitnemende samenvatting van de resultaten van het onderzoek in deze kwestie in de loop der jaren, benevens een naar mijn mening zeer wel gefundeerd oordeel hierop neerkomend: ,Geen van de onderzoekingen is diepgaand en afdoende genoeg geweest, maar optimisme inzake de mogelijkheid van veeteelt op de Savannen is voorshands misplaatst".

Het is hier niet de plaats om over dit onderwerp verder uit te wijden en het uit te spinnen, aanvullend en aansluitend onderzoek zal zeker moeten plaats vinden.

Maar ik wil de verzuchting slaken, dat het toch jammer is, dat van de aanwezigheid van een man als Dr Frickers, met die kennis van zaken, nu geen gebruik meer kan worden gemaakt.

Niet, dat zulks, toen hij er verbleef, wel het geval was.

Des Heren Frickers' ervaring in Suriname inzake waardering voor zijn arbeid is niet altijd even stimulerend geweest. Waardering, ja, in woorden, maar in middelen en personeel ....? $\mathrm{Nu}$ is de heer Frickers eerzaam directeur van een slachthuis in Nederland, naar zijn ervaring wordt niet meer gevraagd.

Wij bezitten wel zijn verhandelingen en rapporten en gelukkig vinden wij in dit jaarverslag de boven genoemde belangrijke samenvatting over het veeteelt vraagstuk op de Savannen.

Maar het zou iets anders zijn, als Frickers daar zelf had kunnen doorwerken en verder opbouwen.

Wij hopen en vertrouwen, dat bij de verdere opbouw van Suriname aan de veeteelt voldoende aandacht zal worden geschonken. Soms slaat ons de schrik wel eens om het hart, dat dit niet het geval zal zijn, maar als het gebeurt zullen wij toch Dr. Frickers zeer node missen. Had het alles niet anders kunnen lopen, met een beetje meer goede wil van zekere zijde?

De andere reeds door mij genoemde bijdrage, n.l. die van Mevr. Droogleever Fortuyn, over het legeren van rijst-variëteiten is eveneens, hoewel van geheel ander karakter en opzet, zeer belangrijk en uiterst lezenswaard.

Ook hier is weer met weinig materiaal en belachelijk kleine credietjes (en natuurlijk veel belangstelling) gewoekerd. Het vraagstuk van de legering van rijst-variëteiten is immers van het uiterste belang, met het oog op de steeds verder gaande mechanisatie in de rijstcultuur. Het is wel gebleken, hoe economisch, 
als het maar lukt, het gebruik van de combine is. Ik heb mij er inderdaad echter zelf van kunnen overtuigen, dat het maaien bij legerende rijst maar heel slecht gaat en daarom zou het een uitkomst zijn, als men erin slaagde, dit legeren onder de knie te krijgen.

Uit het verslag van Mevr. Droogleever Fortuyn blijkt wel dat het vraagstuk allerminst eenvoudig is en het legeren niet kan worden toegeschreven aan éne erfelijke factor, die men in de hand zou kunnen proberen te krijgen, maar dat het een geval is van een complex van eigenschappen, die men niet zo gemakkelijk beheerst.

Wij spreken de hoop uit in volgende jaarverslagen hieromtrent meer te vernemen, ook Mevr. Droogleever Fortuyn is inmiddels weer vertrokken; wie heeft dit werk overgenomen?. Maar het fragmentarische van Suriname kennende zijn wij tegelijk beducht. Er zal b.v. wel geen crediet voor uitgetrokken zijn geweest of om een andere reden niet dadelijk systematisch erop voortgebouwd.

Wat verder het verslag betreft: Het jaar 1945 is daarom zo belangrijk geweest, omdat dit het eerste na-oorlogse jaar was, waarin weder contact met Nederland bestond en daardoor reeds weer afzet van Landbouwproducten naar Nederland blijkt te bestaan.

Natuurlijk is deze afzet nog maar gering, Suriname heeft zich in de oorlogsjaren op andere markten moeten richten; zoals: Curaçao, Aruba, de Verenigde Staten en de Britse en Franse gebieden in West-Indië. De uitvoer naar Nederland kon in dat jaar natuurlijk nog maar in zijn kinderschoenen staan en daarom is het goed gezien van het verslag, dat het tevens een overzicht geeft van hoeveel en waarheen in de voorafgaande jaren van de oorlog werd geëxporteerd. Het moet mij dan echter dadelijk van het hart, dat men om tot een juist inzicht te komen, met tal van moeilijkheden kampt.

De tabellen volgen niet overal hetzelfde schema, de getallen in verschillende tabellen, die zouden moeten kloppen, doen dat niet altijd. Zo klopt de uitvoer van padi in kilogrammen voor 1942 niet overal in de eerste tabel na blz. 66 met de laatste tabel waarin de uitvoer van alle landbouwproducten wordt gegeven en er zijn meer van die nietkloppende gegevens.

Zo staat op blz. 42 te lezen, dat op drassige velden bij irrigatieproeven $0.181 / \mathrm{sec}$. aan water werd gesuppleerd, op natte velden bijna 0.51 doch verder op de zelfde blz., dat de verdamping op drassige velden hoger is dan bij natte, waaruit zou volgen, dat 
dan de suppletie groter zou moeten zijn. Het verschil wordt niet verklaard.

Bij nauwkeurig bezien van de tabellen zijn ook nog andere aanmerkingen te maken. Berekent men uit de eerste tabel de binnenlandse consumptie aan rijst of padi uit de productie en de uitvoer, dan komt men tot consumptiecijfers die bij de geleidelijk toenemende bevolking van 1941 tot 1945 in wonderlijke verhoudingen tot elkaar staan.

Een ander bezwaar dat ik voortdurend heb gevoeld, is, dat geen of onvoldoende toelichting wordt gegeven bij de tabellen. Het was niet te verwachten, dat de export b.v. van landbouwproducten in oorlogstijd gelijkmatig verliep. Te verwachten was in tegendeel, dat onregelmatigheden zouden optreden. Maar hier en daar zijn die onregelmatigheden toch wel heel groot en zou een toelichting op zijn plaats zijn geweest.

Toch is dit nog te overkomen; bepaald als een gebrek heb ik echter gevoeld de afwezigheid van enige toelichting op de productiecijfers. Ook hierin zijn grote veranderingen te constateren. De cijfers hebben hier en daar zelfs een hectisch verloop, waarvoor niet altijd maar dadelijk door de lezer een verklaring kan worden gevonden. Hetzelfde geldt voor het beplante areaal.

Ten aanzien van deze moeilijkheden die men ontmoet, wanneer men de cijfers nader gaat bestuderen, is nog te zeggen, dat die moeilijkheden er niet minder op worden, wanneer men zoals ondergetekende weet hoe en door wien b.v. in afgelopen jaren aanvankelijk het beplante oppervlak werd geschat. Het is de verdienste van het Departement van Landbouw-Economische Zaken geweest, dat het zich van deze bronnen van fouten bewust was, en daar, al weer zover de gelden het toelieten, zoveel mogelijk verbetering in heeft gebracht.

Dan is het b.v. voor de buitenstaander ook van belang te weten, hoe de proefsnitcijfers worden verkregen.

Vóórdat aan proefsnitten werd gedaan, werd in de opbrengsten eenvoudigweg een slag geslagen, evenals in het beplante oppervlak (zie boven). Het resultaat was dan ook funest, en de ,Surinaamse Verslagen" (vroeger Verslag van Bestuur en Staat geheten), waren voorzover zij zich op dit cijferterrein begaven, dan ook te rangschikken onder de categorie: „Aardigheden voor rekenaars".

Waar het Departement van Landbouw-Economische Zaken daarin verbetering heeft gebracht, mag het daar ook wel degelijk meer van vertellen. 
In het Verslag van 1945 heb ik niets gevonden, wat ook maar enige beschrijving geeft van de activiteit van de Landbouw Voorlichtingsdienst. $\mathrm{Al}$ is dit ook al weer een wijdse titel voor een zo klein dienstje, het doet toch veel goede dingen, en een beschrijving van de werkwijze en resultaten zou zeker op zijn plaats zijn geweest.

Een Landbouwverslag behoort naar mijn mening ook meer aandacht te schenken aan culturen die geen bevolkingsculturen zijn, zoals de suiker- en de bananencultuur. De suikercultuur komt er in het verslag maar bekaaid af.

De geweldige achteruitgang in de productie wordt niet verklaard en de enkele alinea die eraan wordt gewijd op blz. 52 is onbevredigend. Moeten wij geloven dat de kolossale achteruitgang alleen te wijten is aan gebrek aan arbeiders en seizoenonzekerheden?

De bananencultuur had zeker uitgebreider moeten worden behandeld. Over de proeven van de Surinaamse Bananen Maatschappij, ook al vonden die niet plaats onder Gouvernements auspicieën, had zeker wel iets mogen worden vermeld.

Het in vorige verslagen gebruikelijk overzicht van de activiteit van de Irrigatie Dienst, die, hoewel resorterend onder het Departement van Openbare Werken, toch nauw met Landbouw samenwerkte, wordt in dit verslag niet aangetroffen.

Wij moeten het hier bij laten. Deze aanmerkingen, die gemaakt moesten worden, willen echter niets afdoen aan de waardering, waarmee in de aanvang werd begonnen, en die het Departement, met erkenning van onvolkomenheden en feilen, voor zijn activiteit, met zo geringe middelen, toekomt. Inmiddels is de Directeur, Dr D. S. Fernandes, vertrokken, en is de leiding van het Departement in andere handen gekomen.

Daar ten tijde van dit verslag de Heer Fernandes nog in vollen dienst was, is het hier niet de plaats, op de verdiensten van een scheidende Directeur in te gaan. Wellicht mag ik echter toch nog even opmerken, dat het om de verdiensten van Dr. Fernandes voor de citruscultuur wenselijk was geweest, dat hij grondige aandacht aan deze cultuur in zijn verslag had besteed.

$\mathrm{Te}$ grote bescheidenheid is ook niet goed. 